\title{
Total arterial revascularization on OPCABG with the exclusive use of two internal mammary arteries - a single center ten-year study analysis
}

\author{
S Prapas*, I Panagiotopoulos, I Linardakis, V Panagiotakopoulos, K Katsavrias, D Pavlopoulos \\ From 23rd World Congress of the World Society of Cardio-Thoracic Surgeons \\ Split, Croatia. 12-15 September 2013
}

\section{Background}

Our aim is to record and present our ten-years' experience on total arterial revascularization treatment of coronary artery disease with the exclusive use of both internal mammary arteries on OPCABG.

\section{Methods}

From February 2001 till September 2011, 1077 patients underwent a total arterial revascularization OPCABG procedure with the use of both internal mammary arteries. The "non-touch Aorta Technique" was utilized and the " $\pi$-graft", the " $y$ - graft", "t-graft", " $\lambda$-graft" and " $\psi$-graft" techniques were employed. The mean age of our population was 66 years, with a male majority of 84.5\%. 72 patients were diabetics (6.7\%), 260 patients with LV dysfunction ( $E F<45 \%), 73$ (7.2\%) with renal insufficiency of which 19 under dialysis (1.8\%).

\section{Results}

The mean number of peripheral arterial anastomoses consisted of 2.8/patient. 569 patients had sequential anastomoses performed with a mean 1.35 /patient. Atrial fibrillation was observed in 206 patients (19.1\%). IABP was employed on 19 patients preoperatively and 14 patients postoperatively. Emergency revision was performed on 17 patients (1.6\%), 14 (1.3\%) for hemorrhage and 3 for hemodynamic instability $(<0.3 \%)$. Sixteen patients remained under prolonged intubation $>48 \mathrm{hrs}(1.6 \%)$. Postoperative neurological complications were observed in 5 patients $(<0.5 \%)$ with stroke. Twenty-two patients $(2 \%)$ presented sternal wound infection, 10 of which were diabetic ( 2 insulin and 8 non-insulin dependent).

* Correspondence: sprapas@dunanthospi.gr

Cardiac Surgery Dpt., Henry Dunant Hospital, Athens, Greece
GI complications were observed in 18 patients (1.8\%). Psychiatric help was assessed on 8 patients $(0.7 \%)$. Long term mortality consisted of 25 and hospital mortality of 7 patients $(<1 \%)$.

\section{Conclusions}

Total arterial revascularization, with the use of both internal mammary arteries, on off pump beating heart surgery is a feasible combination with excellent results when performed by experienced cardiac surgeons.

Published: 11 September 2013

doi:10.1186/1749-8090-8-S1-0198

Cite this article as: Prapas et al:: Total arterial revascularization on OPCABG with the exclusive use of two internal mammary arteries - a single center ten-year study analysis. Journal of Cardiothoracic Surgery 2013 8(Suppl 1):0198.

Submit your next manuscript to BioMed Central and take full advantage of:

- Convenient online submission

- Thorough peer review

- No space constraints or color figure charges

- Immediate publication on acceptance

- Inclusion in PubMed, CAS, Scopus and Google Scholar

- Research which is freely available for redistribution 